\title{
Technical Efficiency of Yam Producers: The Case of the Municipality of Glazoué in Benin
}

\author{
Jean Adanguidi ${ }^{1} \&$ Cocou Jaurès Amegnaglo ${ }^{2}$ \\ ${ }^{1}$ Faculté des Sciences Economiques et de Gestion, Université d'Abomey Calavi, Bénin \\ ${ }^{2}$ Ecole d'Agrobusiness et de Politiques Agricoles, Université Nationale d'Agriculture, Bénin \\ Correspondence: Jean Adanguidi, Faculté des Sciences Economiques et de Gestion, Université d'Abomey Calavi, \\ Bénin. E-mail: a60j60@gmail.com
}

\author{
Received: December 19, 2019 \\ Accepted: March 11, 2020 \\ Online Published: May 26, 2020 \\ doi:10.5539/jsd.v13n3p24 \\ URL: https://doi.org/10.5539/jsd.v13n3p24
}

\begin{abstract}
In Benin republic, yam plays an important role both in production systems and in people's food security and trade. In view of the decline in agricultural yields in recent years combined with strong population growth, it is essential today to analyse the technical efficiency of yam producers in order to formulate the best recommendations for relaunching yam production. The objective of this paper is to analyse the technical efficiency of yam producers in Benin and its determinants. To achieve this objective, data were collected from 150 yam producers living in the Municipality of Glazoué. A stochastic production frontier is used to analyse the technical efficiency of the yam producer. The results revealed that the mean efficiency score of producers is around $80 \%$. This implies that yam production could be increase by $20 \%$ through better use of available resources such as land, labour, herbicides, taking into account the state of technology. Access to credit and mobile phone ownership increase the inefficiency of actors while experience in agricultural production, age and household size reduce the inefficiency of producers.
\end{abstract}

Keywords: Benin, determinants, stochastic frontier production function, technical efficiency, yam

\section{Introduction}

Yam is one of Benin's main food crops. It plays an important role both in production systems and in people's food security and trade. It also plays an important role in activating social and cultural identities. In several traditional yam-producing localities, rituals are organized to mark the release of the new yam. But the consumption of yam and its by-products goes well beyond its traditional era of production and extends to the cities (Bricas \& Attaie 1998; Adanguidi, 2000). Its production, estimated at 1.45 million tonnes in 2008, increased to 2.65 million tonnes in 2015 (MAEP, 2017), an 83\% increase over 8 years. On the other hand, over the same time horizon, yam yield fell from 14.48 tonnes/Ha in 2008 to 13.08 tonnes/Ha in 2015, a 10\% decrease compared to its 2008 level. This means that the increase in production observed over the period would probably be due to extensive agriculture. At the same time, Benin is facing significant population growth: The country's population has tripled in 34 years, from 3331210 inhabitants according to the RGPH1 of 1979 to 10008749 inhabitants according to the RGPH4 of 2013). However, according to Bricas (1999), Benin is one of the countries where per capita yam consumption has remained high since the $1960 \mathrm{~s}$ (more than $40 \mathrm{~kg} / \mathrm{person} / \mathrm{year}$ on average). In the Strategic Plan for the Revival of the Agricultural Sector (PSRSA 2011-2015), the Government of Benin had selected yams as one of the thirteen priority agricultural sectors to be promoted. However, in view of the decline in yam yields in recent years, it is vital to analyse the efficiency of yam producers in order to better formulate recommendations for policy makers. According to Farrell (1957), improving efficiency has a positive impact on productivity by saving resources. This reduces discrepancies between current and potential results (Audibert, 1997).

In Benin, few studies have struggled to analyse the technical efficiency of yam producers. This paper targets to close this gap through the case study of Glazoué, a locality of Benin which is very well known for its yam production and which also hosts the country's largest yam market. The article will be presented as follows: The first will review the empirical literature on the subject. The second part will be devoted to the methodological framework of the study. In the third part, we will discuss the results of the study. In the last part, we will draw conclusions and make some recommendations. 


\section{Literature Review}

Two methods are generally used for efficiency studies: (1) the first one is the parametric method which is called stochastic production frontier; (2) and the second one is called non-parametric method and is known as DEA (Data Envelopment Analysis). Studies reveal strong potential for increasing agricultural production if the various agricultural inputs were efficiently used. Degla (2015) found, based on a sample of cashew nut producers in Benin, that the average technical efficiency score was 63\%. Kpenavoun Chogou, Gandonou, and Fiogbe (2017) estimated the average technical efficiency score of pineapple producers in southern Benin at $67 \%$. Amegnaglo (2018) and Toléba, Biaou, Zannou, and Saïdou (2016) found that growth in current maize production of about $25 \%$ and $20 \%$ respectively can be accomplished in the short term by adopting best agricultural practices and addressing socio-economic and structural constraints. Regarding yam production, the studies suggested that inputs were not being used efficiently in their respective study areas, a better level of production would have been achieved if the resources had been used efficiently all other things being equal (Ekunwe \& Orewa, 2007; Ogunniyi \& Ajao, 2012; Reuben \& Barau, 2012). Ekunwe and Orewa (2007) found that the average technical efficiency score of yam producers in Nigeria is 62\%, Ogunniyi and Ajao (2012) estimated that the mean technical efficiency score of yam producers in Oyo State in Nigeria is 54.4\%. Awoniyi, Abiodun, and Titus (2006) suggested that the technical efficiency of yam producers in Ekiti State, Nigeria, varies between 76 and $80 \%$ depending on the production system.

Studies revealed that the main determinants of agricultural production in general and yam production in particular in Africa are: labour, financial resources and agricultural inputs such as fertilizers, improved seeds, agricultural equipment (Amegnaglo, 2018; Aminou, 2018; Bempomaa \& Acquah, 2014); farm size and marital status (Aminou, 2018; Donye, Gwary, Nuhu, \& Zhintswen, 2012); Farmers' education, family work, access to extension services and agricultural credit and farmers' experience (Aminou, 2018; Etim, Thompson \& Onyenweaku, 2013); and land, yam seeds, family work, education and fertilizer (Shehu, Iyortyer, Mshelia, \& Jongur, 2010). Geographic factors also seem to play a role in agricultural performance in Africa.

The main factors affecting the efficiency of yam producers vary according to the authors. Ekunwe and Orewa (2007) suggested that experience and age increase the technical efficiency of yam producers in Kogi State, Nigeria. Ogunniyi and Ajao (2012) indicated that farm size, hired labour, yam variety and equipment are the main factors influencing variations in yam production in Oyo State, Nigeria. The determinants of producer inefficiency are farming experience, diversification and access to agricultural extension (Awoniyi et al., 2006; Ogunniyi \& Ajao, 2012). The main determinants of yam production in Taraba State in Nigeria are the amount of seed used, farming experience and farm size (Reuben \& Barau, 2012). In addition, the same authors point out the underutilization of seeds, chemical fertilizers (Note 1) and land in yam production and the overuse of hired labour, herbicides and insecticides. Market imperfections justify the inefficient use of production factors. The high cost of chemical fertilizers, labour, and the difficulties of storing yam seeds push producers to limit the area of yam cultivated.

\section{Methodology}

Two main families of methods are used to measure efficiency according to the Farrell conception: parametric and non-parametric methods. The parametric methods assume that the frontier function is represented by a function with explicit parameters (Cobb-Douglas or Translog) while the non-parametric methods consider that the production process studied does not a priori have a well-defined functional form. The non-parametric approach uses the DEA (Data Envelopment Analysis, DEA) method introduced by Charnes, Cooper, and Rhodes (1978). The DEA method consists in using mathematical programming to construct a fragmented production frontier from all the data of the production units. The DEA approach allows the model to be estimated by constant returns to scale (Constant Returns to Scale, CRS) or variable returns to scale (Variable Returns to Scale, VRS). In addition, the DEA approach allows the estimation of multi-product and multi-input production frontiers without the imposition of additional restrictions. However, non-parametric methods do not take into account random variations (weather conditions, parasitic episodes, etc.) that are not under the control of farmers, which could influence the efficiency or inefficiency of a farm. Also, non-parametric methods do not allow to test the statistical properties. Finally, non-parametric methods are very sensitive to extreme observations, which are largely responsible for determining this function, and recent developments in parametric approaches make them more robust, less sensitive to extreme values, measurement errors and statistical noise and allow statistical testing (Cazals, Florens, \& Simar, 2002; Simar \& Wilson, 2007, 2011). Parametric methods are most commonly used in sectors with low random variations or in multi-product and multi-input production sectors.

Parametric methods (Stochastic Frontier Method, SFA) take into account most of the inconveniences of 
non-parametric methods. The SFA approach makes it possible to consider exogenous factors (climatic conditions, pest outbreaks, etc.) that are out of farmers' control, but which can affect the producers' performance. SFA approach can also control for measurement errors, statistical noise and differential technological adoption rate (Aigner, Lovell, \& Schmidt, 1977; Meeusen \& van Den Broeck, 1977).

Based on Farrell's (1957) conception of technical efficiency, Aigner, Lovell, and Schmidt (1977) and Meeusen and van Den Broeck (1977) suggested that the production technology of an agricultural product can be represented by a stochastic frontier production function. The model is as follows:

$$
Y_{i}=f\left(X_{i}, \beta\right) \exp \left(\varepsilon_{i}\right)=f\left(X_{i}, \beta\right) \exp \left(v_{i}-u_{i}\right) i=1, \ldots, N
$$

where $Y_{i}$ is the level of production of a producer $i ; f\left(X_{i}, \beta\right)$ is a Cobb-Douglas or Translog production function and represent the maximum feasible quantity of production possible $X_{i}$ (input vector) and $\beta$ is a vector of parameters. $\varepsilon_{i}$ is the error term composed of two independent elements $v_{i}$ and $u_{i}$ as $\varepsilon_{i}=\left(v_{i}-u_{i}\right)$. Production may differ from the deterministic frontier due to random shocks $v_{i}$ which may be positive or negative, or due to a non-negative inefficiency error term, and $u_{i}$ which reduces production $\left(u_{i} \geq 0\right) . v_{i}$ is identically distributed with a zero mean and constant variance assumed to be independent of $u_{i}$.

The technical efficiency (TE) of the $\mathrm{i}^{\text {th }}$ producer is:

$$
\left.T E_{i}=\exp \left(-u_{i}\right)=\frac{f\left(X_{i}, \beta\right) \times \exp \left(v_{i}-u_{i}\right)}{f\left(X_{i}, \beta\right) \times \exp \left(v_{i}\right)}\right)
$$

TE is the relationship between real and potential output. The maximum value the TE can take is 1 while the minimum is 0 , reflecting the inefficiency. The imposition of an appropriate distribution form for the inefficiency error term $\left(\mathrm{u}_{\mathrm{i}}\right)$ is required in order to estimate correctly the parameters of the production function. Assuming that the inefficiency terms follow a semi-normal distribution which means $u_{i} \sim i i d N^{+}\left(0, \sigma_{u}^{2}\right)$, the technical efficiency is defined as follows:

$$
u_{i}=Z_{i} \delta+\theta_{i}
$$

where $Z_{i}$ is a vector of independents variables associated with the technical inefficiency and $\theta$ is the error term of inefficiency.

\subsection{Model Specification}

A Cobb-Douglas production was chosen because it is flexible, and its returns to scale and is easily interpreted (Bravo-Ureta \& Evenson, 1994).

$$
Y_{i}=\alpha_{i}+\sum_{j=1}^{J} \beta_{j} X_{j i}
$$

where we simultaneously model the average of the subsequent distribution of inefficiency at the farm level as $\exp \left(\sum_{m=1}^{M} \delta_{m} Z_{m}\right) . \mathrm{Y}_{\mathrm{i}}$ is the production of yam (tons) produced during the 2018 season by the $\mathrm{i}^{\text {th }}$ producer; $\mathrm{X}$ is a set of inputs, namely: land size, labour, seeds, weedicides, capital, fertilizers, $\beta$ represents parameters to be estimated; $v_{i}$ denotes random shocks; $u_{i}$ is the non-negative unilateral error representing inefficiency terms. The model specification used is described in equation (5) below.

$$
\begin{array}{r}
\log (\text { Output })= \\
\beta_{0}+\beta_{1} \log (\text { capital })+\beta_{2} \log (\text { hired_labour })+\beta_{3} \log (\text { family_labour })+\beta_{4} \log (\text { Land })+ \\
\beta_{5} \log (\text { herbicides })+\varepsilon
\end{array}
$$

where Output corresponds to the yam production (tons) and $\varepsilon$ corresponds to the error term of the equation. Table 1 provides details on the variables used in the regression analysis and their measures. 
Table 1. Description of the study variables

\begin{tabular}{|c|c|}
\hline Variables & Description \\
\hline Capital & $\begin{array}{l}\text { Total cash expenditure incurred for all yam cultivation operations (US } \\
\text { dollar/ha) }\end{array}$ \\
\hline Family_labour & Total family labour used for all yam cultivation operations (days/ha) \\
\hline Hired_labour & Total rented labour used for all operations related to yam cultivation (days/ha) \\
\hline Land & Size of land devoted to yam production (ha) \\
\hline Age & Age in years \\
\hline Herbicide & Quantity of herbicide used in yam production (1/ha) \\
\hline Access to Credit & If has access to formal institutional credit; Yes $=1$; Otherwise $=0$ \\
\hline Experience & Number of years of experience in yam production by the farmer \\
\hline Household size & $\begin{array}{l}\text { Number of members of a farming family sharing food from a single source, } \\
\text { living in the same concession and recognizing the authority of a single person } \\
\text { called head of household }\end{array}$ \\
\hline Education & $\begin{array}{l}\text { Formal education received by a farmer; } 0=\text { none; } 1=\text { primary and } 2=\text { beyond } \\
\text { primary }\end{array}$ \\
\hline Possession of mobile phone & If has a mobile phone; Yes $=1$; Otherwise $=0$ \\
\hline Yield & Yam production per unit area $(\mathrm{kg} / \mathrm{ha})$ \\
\hline
\end{tabular}

\subsection{The Inefficiency Model}

The inefficiency model of yam producers is defined as follows:

$$
U_{i}=\delta_{0}+\sum_{m=1}^{8} \delta_{m} Z_{m i}
$$

Where $\delta$ is a vector of parameters to be estimated; $Z$ is the vector of variables that are possible source of inefficiency for the yam producer i. It is composed of the age of the yam producer $\left(Z_{1}\right)$, the squared age of the producer $\left(Z_{2}\right)$, the producer's experience $\left(Z_{3}\right)$, the size of the producer's household $\left(Z_{4}\right)$, the access to agricultural credit $\left(Z_{5}\right)$, the area of yam cultivated $\left(Z_{6}\right)$, the producer's education level $\left(Z_{7}\right)$, hired labour' use $\left(Z_{8}\right)$, and finally the possession of a mobile phone $\left(Z_{9}\right)$. The variables that explain the farmer inefficiency equation are explained in Table 1. This study adopts a two-step procedure to estimate the technical efficiency of yam producers. Fractional Regression Model proposed by Papke and Wooldridge (1996) is used for the second step estimation since efficiency scores are proportions. Maximum likelihood method was used to estimate the production functions and inefficiencies of yam producers. The estimate was made in a single step on STATA from the FRONTIER program.

\subsection{Study Area and Sampling Techniques}

First, we chose the study region. The area that can be described as Benin's "Yam belt" consists of the departments of Alibori, Atacora, Borgou, Donga, Zou and Collines, which, according to statistics from the Ministry of Agriculture, Livestock and Fisheries, account for nearly $99 \%$ of national yam production over the period 1997-2017. In this area, the Municipality of Glazoué located in the department of Collines is known to be a large yam production area (table 2) and also has the largest yam market in Benin. We have therefore selected this municipality for this study. 
Table 2. Average land under yam production and average yam production in the Municipalities of the Department of Collines between 1996 and 2017

\begin{tabular}{lcc}
\hline Municipality & Average cultivated area (in Hectare) & Average production (in tonnes) \\
\hline Bantè & 13551 & 51583 \\
Dassa-Zoumè & 5179 & 21182 \\
Glazoué & 73891 & 239476 \\
Ouessè & 15678 & 57523 \\
Savalou & 10995 & 43815 \\
Savè & 7271 & 25757 \\
\hline
\end{tabular}

The second step of the selection process was the random selection of 12 villages in Glazoué. The choice of villages was based on interviews with several resource persons, extension agents and producers in the commune. The third step was the random selection of farmers. The sample size for the study is 150 yam producers.

\section{Results}

\subsection{Descriptive Statistics}

Yam producers are almost entirely male (Table 3 ). On average, the producer is 43 years old and has been growing yams since 19.42 years.

Table 3. Socioeconomic characteristics of respondents

\begin{tabular}{|c|c|c|}
\hline Variables & Mean & Standard deviation \\
\hline Gender (percentage of men) & 98.67 & 11.51 \\
\hline Age (years) & 42.95 & 09.99 \\
\hline Experience in yam (years) & 19.42 & 10.68 \\
\hline Household size & 08.95 & 03.73 \\
\hline Access to credit (\%) & 22.00 & 41.56 \\
\hline Access to market (\%) & 97.33 & 16.16 \\
\hline Educational level achieved & - & - \\
\hline Not at all educated....................... & 44.67 & 49.88 \\
\hline Primary school........................... & 38.00 & 48.70 \\
\hline Beyond primary school.................. & 17.33 & 37.98 \\
\hline Yield of yam (t/ha) & 03.39 & 02.85 \\
\hline Herbicide application (L/ha) & 02.26 & 03.80 \\
\hline Capital (USD/ha) & 40.03 & 25.25 \\
\hline Work (man day /ha) & 119.91 & 63.71 \\
\hline Field size (ha) & 01.68 & 01.46 \\
\hline
\end{tabular}

\subsection{Stochastic Production Function}

The estimated parameters of the stochastic production function are summarised in Table 4. The results of the estimation indicate the presence of technical inefficiency among yam producers in the municipality of Glazoué. The estimated lambda coefficient is significant and well above zero. The hypothesis of no inefficiency is therefore rejected at $1 \%$.

The estimation of the stochastic production model reveals that only land and herbicide factors have a significant and positive effect on yam production in the municipality of Glazoué. Yam production is very poorly mechanized (use of hoe and cutting) and very few producers use fertilizers. The few producers who use fertilizers use very small amounts of fertilizer. The increase in the area cultivated by one percent will contribute 
to an increase in yam yields by 0.82 percent. The increase in areas cultivated is generally on new land that is generally rich, justifying the positive effect of cultivated areas on yam yields. Also the low use of the market inputs (off-farm inputs such as seeds, fertilizers, herbicides, equipment, etc.) is another reason for the positive effect of land. Also, the increased use of herbicides contributes to higher yields.

Table 4. Estimation of the stochastic production model

\begin{tabular}{|c|c|c|c|}
\hline Variables & Coefficients & $t$ - value & Prob \\
\hline Log (capital) & -.00330 & -.05 & 0.958 \\
\hline Log (family labour) & .04077 & .86 & 0.391 \\
\hline Log (hired labour) & .00702 & .26 & 0.795 \\
\hline Log (land) & $.82092 * * *$ & 12.60 & 0.000 \\
\hline Log (herbicides) & $.11687^{*}$ & .1 .65 & 0.098 \\
\hline Constant & $.2323 * * *$ & 3.40 & 0.001 \\
\hline Log-likelihood function & & -48.32572 & \\
\hline Sigma square $\left(\delta^{2}\right)$ & .1831 & 4.496 & \\
\hline Lambda $(\lambda)$ & $1.2438 * * *$ & 11.52 & \\
\hline$\delta_{u}^{2}$ & .3335 & 4.2018 & \\
\hline$\delta_{v}^{2}$ & .2681 & 7.7018 & \\
\hline
\end{tabular}

The parameters estimated in the technical inefficiency model revealed that age, agricultural production experience, access to credit, household size and mobile phone ownership affect significantly yam producers' technical inefficiency (Table 5). Age, experience in agricultural production and household size affect significantly and negatively technical inefficiency of yam producers. The results imply that older producers are less inefficient than younger ones. This result is in line with the experience result. Experience allows producers to make rational use of all available resources to the best of the available information. Household size also reduces producer inefficiency. Producers with large households will then have more manpower at their disposal, which will allow them to take better care of their agricultural activities.

Access to agricultural credit and mobile phone ownership increase producers' inefficiency. The positive effect of credit on inefficiency may be due to insufficient access to credit (Diagne \& Zeller, 2001) or credit diversion (Feder, Lau, Lin \& Luo, 1990). The credit obtained for production reasons is then used in part or totally to smooth consumption. Mobile phone ownership affect positively inefficiency of yam producers, which may be due to a diversion of productive resources to this medium.

Table 5. Estimation results of the technical inefficiency model

\begin{tabular}{lrrr}
\hline Technical inefficiency variables & \multicolumn{1}{c}{ Coefficient } & $\boldsymbol{t}$ - value & \multicolumn{1}{c}{ Prob } \\
\hline Age & $-.1175828^{* * *}$ & -3.71 & 0.000 \\
Age*Age & $.0015661^{* * *}$ & 5.00 & 0.000 \\
Experience & $-.0266944^{* * *}$ & -4.23 & 0.000 \\
Household size & $-.0365771^{* *}$ & -1.97 & 0.048 \\
Access to credit & $.2940302^{* * *}$ & 3.11 & 0.002 \\
Area cultivated & .0261199 & 1.18 & 0.237 \\
Primary education & -.1003493 & -0.97 & 0.332 \\
Secondary education & .0663441 & 0.55 & 0.582 \\
Use of hire labour & .083351 & 0.76 & 0.445 \\
Constant & $.2748918^{*}$ & 1.71 & 0.088 \\
Mobile phone ownership & $3.88332^{* * *}$ & 5.73 & 0.000 \\
\hline$*$
\end{tabular}




\subsection{Technical Efficiency of Yam Producers}

The technical efficiency of yam producers varies from 0.39 to 0.94 (Table 6). The mean technical efficiency is estimated at 0.80 , which means that about $20 \%$ of potential technical output is not achieved. Cross-analysis of efficiency scores with producer yields reveals that 64 percent of producers have an efficiency level below $80 \%$ and this majority has an average yield of 2.3 tonnes per hectare. Also the $36 \%$ with an above-average level of technical efficiency have an average yield of 3.6 tonnes of yams per hectare. The correlation rate between the efficiency level and the producer's performance is 0.72 , indicating a strong positive correlation between the two variables. So the most efficient producers have a better yield. Improving the level of efficiency would therefore lead to an increase in the producer's yield.

Table 6. Distribution of technical efficiency scores and the yield

\begin{tabular}{ccccccccc}
\hline Yield & & & & & & & \\
\hline $1000-2000$ & 3 & 5 & 3 & 0 & 0 & 0 & 11 \\
$2001-3000$ & 0 & 0 & 6 & 20 & 15 & 0 & 41 \\
$3001-4000$ & 0 & 0 & 0 & 10 & 49 & 2 & 61 \\
$4001-5000$ & 0 & 0 & 0 & 0 & 21 & 1 & 22 \\
$5001-10000$ & 0 & 0 & 0 & 0 & 8 & 7 & 15 \\
\hline Total & 3 & 5 & 9 & 30 & 93 & 10 & 150 \\
\hline
\end{tabular}

\section{Conclusion}

This study analysed the technical efficiency of yam producers in the Municipality of Glazoue in Benin based on a sample of 150 producers. The results revealed that yam production is very poorly mechanized with little use of off-farm inputs. Production depends mainly on land and labour factors. The average efficiency score of producers is $80 \%$, meaning that yam production could be increased by $20 \%$ through better use of available resources such as land, labour, herbicides and taking into account the state of technology. Producers with low yields have the lowest efficiency scores. Access to credit and mobile phone ownership increase the inefficiency of actors while experience in agricultural production, age and household size reduce the inefficiency of yam producers. Based on the results, decision-makers could improve yam production through better and reliable access to key inputs such as fertilizers, labour, seeds and equipment. An improvement of the institutional environment can also contribute to a reliable access to markets and extension services for farmers.

\section{References}

Adanguidi, J. (2000). La personnalisation de l'impersonnel. Réflexion autour du commerce de l'igname à Cotonou, Bénin. Bulletin de l'APAD, 19, 1-15. Retrieved from http://journals.openedition.org/apad/438

Aigner, D. J., Lovell, C. A. K., \& Schmidt, P. (1977). Formulation and estimation of stochastic frontier $\begin{array}{llllll}\text { production function models. Journal of Econometrics, } 6, & \text { 21-37. }\end{array}$ https://doi.org/10.1016/0304-4076(77)90052-5

Amegnaglo, C. J. (2018). Determinants of maize farmers' performance in Benin, West Africa. Kasetsart Journal of Social Sciences (March, 2018). https://doi.org/10.1016/j.kjss.2018.02.011

Aminou , F. A. A. (2018). Efficacité Technique des Petits Producteurs du Maïs au Bénin. European Scientific Journal, 14(19), 109-134. https://dx.doi.org/10.19044/esj.2018.v14n19p109

Audibert, M. (1997). Technical inefficiency effects among paddy farmers in the villages of the 'Office du Niger', Mali, West Africa. Journal of Productivity Analysis, 8, 379-394. https://doi.org/10.1023/A:1007767508848.

Awoniyi, O., Abiodun, O., \& Titus, B. (2006). Production Efficiency in Yam based Enterprises in Ekiti State, Nigeria. Journal of Central European Agriculture, 7(4), 627-636. https://doi.org/10.5513/jcea.v7i4.404

Bempomaa, B., \& Acquah, H. G. (2014). Technical efficiency analysis of maize production: evidence from Ghana. Applied Studies in Agribusiness and Commerce, 8, 73-79. https://doi.org/10.22004/ag.econ.202884 
Bravo-Ureta, B. E., \& Evenson, R. E. (1994). Efficiency in agricultural production: The case of peasant farmers in eastern Paraguay. Agricultural Economics, 10(1), 27-37. https://doi.org/10.1016/0169-5150(94)90037-X

Bricas, N., \& Attaie, N. (1998). La consommation alimentaire des ignames: synthèse des connaissances et enjeux de la recherche: 21-30. In Berthaud, J., Bricas N., \& Marchaud J-L. (Eds), L'igname, plante séculaire et culture d'avenir. Actes du séminaire international CIRAD-INRAORSTOM- CORAF. Montpellier, France.

Cazals, C., Florens, J.-P., \& Simar, L. (2002). Non parametric frontier estimation: a robust approach. Journal of Econometrics, 106(1), 1-25. https://doi.org/10.1016/S0304-4076(01)00080-X

Charnes, A., Cooper, W. W., \& Rhodes, E. (1978). Measuring the efficiency of decision making units. European Journal of Operational Research, 2(6), 429-444. https://doi.org/10.1016/0377-2217(78)90138-8

Degla, P. (2015). Technical efficiency in producing cashew nuts in Benin's Savanna Zone, West Africa. Quarterly Journal of International Agriculture, 54(2), 117-132. https://dx.doi.org/10.22004/ag.econ.210310

Diagne, A., \& Zeller, M. (2001). Access to Credit and Its Impact on Welfare in Malawi. International Food Policy Research Institute Report 116, Washington, D.C.

Donye, A. O., Gwary; M. M., Nuhu, H. S., \& Zhintswen, A. A. (2012). Assessment of youth involvement in yam production in Wukari local Government area of Taraba State, Nigeria. Agricultureand Biology Journal of North America, 3(8), 311-317. https://dx.doi.org/10.5251/abjna.2012.3.8.311.317

Ekunwe, P. A., \& Orewa, S. I. (2007). Technical Efficiency and Productivity of Yam in Kogi State Nigeria. Journal of Applied Sciences. 7, 1818-1820. https://dx.doi.org/10.3923/jas.2007.1818.1820

Etim, N-A., Thompson, D., \& Onyenweaku, C. E. (2013). Measuring efficiency of yam (Dioscorea spp) production among resource poor farmers in rural Nigeria. Journal of Agriculture and Food Sciences, 1(3), 42-47. Retrieved from http://www.resjournals.org/JAFS/PDF/2...

Farrell, M. J. (1957). The measurement of productive efficiency. Journal of the Royal Statistical Society. Series A (General), 120(3), 253-290. https://dx.doi.org/10.2307/2343100

Feder, G., Lau, L. J., Lin, J. Y., \& Luo, X. (1990). The Relationship between Credit and Productivity in Chinese Agriculture: A Microeconomic Model of Disequilibrium. American Journal of Agricultural Economics, 72(5), 1151-1157. https://dx.doi.org/10.2307/1242524

Kpenavoun Chogou, S., Gandonou, E., \& Fiogbe, N. (2017). Mesure de l'efficacité technique des petits producteurs d'ananas au Bénin. Cahiers Agricultures, 26(2), 1-6. https://doi.org/10.1051/cagri/2017008

MAEP. (2017). Plan Stratégique de Développement du Secteur Agricole (PSDSA) 2025 et Plan National d'Investissements Agricoles et de Sécurité Alimentaire et Nutritionnelle PNIASAN 2017-2021. Cotonou. [in French]

Meeusen, W., \& Van den Broeck, J. (1977). Efficiency estimation from Cobb-Douglas production functions with composed errors. International Economic Review, 18(2), 435-444. https://doi.org/10.2307/2525757

Ogunniyi, L. T., \& Ajao, O. A. (2012). Economic Efficiency of Yam Production in Oyo State of Nigeria. Agriculturae Conspectus Scientificus, 77(4), 217-221.

Papke, L. E., \& Wooldridge, J. M. (1996). Econometric methods for fractional response variables with an application to 401 (k) plan participation rates. Journal of Applied Econometrics, 11(6), 619-632. https://doi.org/10.1002/(SICI)1099-1255(199611)11:6<619::AID-JAE418>3.0.CO;2-1

Reuben, J., \& Barau, A. D. (2012). Resource Use Efficiency in Yam Production in Taraba State, Nigeria. Journal of Agricultural Sciences, 3(2), 71-77. https://doi.org/10.1080/09766898.2012.11884687

Shehu, J. F., Iyortyer, J. T., Mshelia, S. I., \& Jongur, A. A. U. (2010). Determinants of Yam Production and Technical Efficiency among Yam Farmers in Benue State, Nigeria. Journal of Social Sciences, 24(2), 143-148. https://doi.org/10.1080/09718923.2010.11892846

Simar, L., \& Wilson, P. W. (2007). Estimation and inference in two-stage semi-parametric models of production processes. Journal of Econometrics, 136, 31-64. https://doi.org/10.1016/j.jeconom.2005.07.009

Simar, L., \& Wilson, P. W. (2011). Inference by the $\mathrm{m}$ out of $\mathrm{n}$ bootstrap in nonparametric frontier model. Journal of productivity analysis, 36, 33-53. https://doi.org/10.1007/s11123-010-0200-4

Toléba, S. M., Biaou, G., Zannou, A., \& Saïdou, A. (2016). Évaluation du niveau d'efficacité technique des systèmes de production à base de maïs au Bénin. European Scientific Journal, 12(27), 276-299. http://doi.org/10.19044/esj.2016.v12n27p276 


\section{Note}

Note 1. Yam prefers rich soils. It prefers to be at the head of the crop rotation after a wasteland or a long period fallow. A supply of organic fertilizer (crop residues, compost, manure, etc.) and minerals is essential when the soil is getting poorer.

\section{Copyrights}

Copyright for this article is retained by the author(s), with first publication rights granted to the journal.

This is an open-access article distributed under the terms and conditions of the Creative Commons Attribution license (http://creativecommons.org/licenses/by/4.0/). 